\title{
Nutritional Dried Matter, Crude Protein and Crude Fiber on Lowland Tidal Grass Fermented by Probiotic Microorganisms for Use Bali Cattle Feed
}

\author{
Muhakka $^{1 *}$, A Wijaya ${ }^{2)}$ and M Ammar ${ }^{3)}$ \\ ${ }^{1)}$ Department of Animal Husbandry, Faculty of Agriculture, Sriwijaya University, Palembang-Prabumulih Street KM.32 \\ Ogan Ilir, South Sumatra \\ ${ }^{2)}$ Department of Agricultual Technology, Faculty of Agriculture, Sriwijaya University, Sriwijaya University, Palembang- \\ Prabumulih Street KM.32 Ogan Ilir, South Sumatra \\ ${ }^{3)}$ Department of Agronomy, Faculty of Agriculture, Sriwijaya University, Sriwijaya University, Palembang-Prabumulih \\ Street KM.32 Ogan Ilir, South Sumatra \\ *Corresponding author email: muhakka@yahoo.co.id
}

\begin{abstract}
This study was aimed to determine nutritional value of lowland tidal grass fermented by probiotic microorganisms. This study used a completely randomized design and investigated two factors, namely varieties of lowland tidal grass (kumpai tembaga (Ischaemum rugosum), kumpai minyak (Hymenachne amplexicaulis) and kumpai padi (Oryza rufipogon)) and probiotic microorganism concentration (0.3, 0.5, 0.7 and 0.9 percent). The following parameters were observed, including dried matter content, crude protein content and crude fiber content. The results showed that the use of probiotics have significant effects on crude protein content and crude fiber content. In conclusion, the use of probiotics can improve the nutritional value of grass. The best result was obtained on kumpai tembaga grass (Ischaemum rugosum) fermented with $0.7 \%$ probiotic microorganism.
\end{abstract}

Keywords: nutritional evaluation, lowland tidal grass, fermentation, probiotics microorgansms

Abstrak. Penelitian ini bertujuan untuk menentukan nilai nutrisi rumput tidal dataran rendah yang difermentasi menggunakan mikroba probiotik. Penelitian menggunakan rancangan acak lengkap dan mengamati dua faktor, yaitu varitas rumput tidal dataran rendah (kumpai tembaga (Ischaemum rugosum), kumpai minyak (Hymenachne amplexicaulis) dan kumpai padi (Oryza rufipogon)) dan mikroba probiotik $(0,3$; 0,$5 ; 0,7$ dan 0,9 persen). Parameter yang diamati meliputi kandungan bahan kering, protein kasar, dan serat kasar. Hasilnya menunjukkan bahwa penggunaan probiotik memiliki pengaruh nyata terhadap kandungan protein kasar dan serat kasar. Dapat disumpulkan bahwa penggunaan probiotik dapat meningkatkan nilai nutrisi dari rumput. Hasil terbaik diperoleh pada rumput kumpai tembaga (Ischaemum rugosum) yang difermentasi menggunakan $0,7 \%$ mikroba probiotik.

Kata kunci: evaluasi nutrisi, rumput tidal dataran rendah, fermentasi, mikroba probiotik

\section{Introduction}

Bali beef cattle belong to the ruminant livestock with high reproduction, good-quality carcass and low-fat content. Low productivity of ruminant livestock in the tropical regions was caused by poor quality feed, characterized by low protein content, high crude fiber content and low digestibility. Grass fermented by probiotic microorganisms offered high nutritional value and better digestibility (Khuluq, 2012). Therefore, probiotic microorganisms allows better production for feed preparation.

Bali beef cattle are tolerant to local feed and can endure lacking feed although losing drastic weight afterwards; however, sufficient good quality feed will cause considerably rapid weight gain. This phenomenon is called compensatory growth. Therefore, it is essential to upgrade feed quality especially fiber to maintain good productivity even in dry 
season (Tanuwiria et al., 2006, Farizaldi, 2011) during which lowland tidal grass is prevalent in South Sumatera province. Indonesia has a total of 13.3 million ha of lowland tidal area spread in Sumatera, Kalimantan and Irian Jaya (Ali et al., 2012).

There are several kinds of lowland tidal grass which have been identified and used for livestock feed, including kumpai minyak (Hymenachne amplexicaulis) grass, kumpai tembaga (Hymenachne acutigluma) grass, and padi hiang (Oryza rufipogon) grass. Despite high productivity, tidal grass has poor quality and high crude fiber. Improving the nutritional values through physical, chemical and enzymatic processing as well as fermentation is to ensue. The use of probiotic microorganisms in livestock feed fermentation is expected to hydrolize crude fiber in grass to improve feed digestibility (Allaily et al., 2011). According to Farizal (2008), suplement can improve digestibility of Hymenachne amplexica. Wina (2005) proposed the use of probiotic microorganisms to increase livestock productivity. Muhakka et al., (2014) used bioplus probiotics of $75 \mathrm{~g}$ per period in Bali beef cattle to gain $0.78 \mathrm{~kg} / \mathrm{head} /$ day. This research was aimed to evaluate the nutritional values of lowland idal grass using probiotic microorganisms.

\section{Materials and Methods}

The research was conducted at laboratory for Livestock Feed and Nutriotion, Faculty of Agriculture, Sriwjaya University, from August to October 2011. Meterials used in this study were Hymenachne acutigluma (kumpai tembaga) grass, Hymenachne amplexicaulis (kumpai minyak) grass, and Oryza rufipogon (kumpai padi) grass, probiotic microorganisms and chemical materials needed for in vitro measurement of digestibility, whereas the following equipments were used, including sickle, knife, pair of scale, plastic ware and stoppered glass.
The research used Completely Randomized Design with two factors, to comprise 12 treatment combinations each with 3 replicates (Table 1). The factors were varieties of swamp grass (kumpai tembaga (Ischaemum rugosum) namely kumpai minyak (Hymenachne amplexicaulis) and kumpai padi (Oryza rufipogon)) and probiotic microorganism, commercially known as effective microorganisms or $\mathrm{EM}_{4}(0.3,0.5,0.7$ and 0.9 percent). The obtained Data were subject to analysis of variance (Steel and Torrie, 1993) then Least signifance Difference to measure the difference across treatments.

\section{Fermentation of lowland tidal grass}

Probiotic microorgansms were utilized in grass fermentation. Grass materials were cut 5 $\mathrm{cm}$ long and mixed with probiotic microorganisms according to the treatment and added with $0.6 \%$ urea (Lembah Hijau Multifarm, 1999). The samples were packed with plastic pocket, humidified with water to reach $60 \%$ relative humidity, and fermented for 21 days. The fermentation product was then wind-dried prior to proxymate analysis and in vitro digestibility.

\section{Measurement of various parameters}

Percentage of dry matters was measured by oven-drying the samples at $105^{\circ} \mathrm{C}$. After a few hours, the samples were taken out and weighed. This step was repeated several times to obtain constant weight which was then multiplied with the fresh weight to get dry matter content.

To calculate nitrogen content, sample was subjected to Kjeldahl treatment. Sulphuric acid was used along with catalyst agent and heating. Organic matter of the sample was oxidized by sulphuric acid to give ammonium sulphate, whereas excessive sulphuric acid would be neutralized with sodium hydroxide to form base solution. The sample was then distilled in acidic medium to obtain nitrogen quantitatively. 
Table 1. Combination treatment between probiotics and type of marsh grass

\begin{tabular}{lccc}
\hline $\begin{array}{l}\text { Dosage of } \\
\text { Probiotics }\end{array}$ & \multicolumn{3}{c}{ Type of Lowland Tidal Grass } \\
\cline { 2 - 4 } & $\begin{array}{c}\text { Ischaemum } \\
\text { Rugosum (R1) }\end{array}$ & $\begin{array}{c}\text { Hymenachne } \\
\text { amplexicaulis (R2) }\end{array}$ & $\begin{array}{c}\text { Oryza } \\
\text { rufipogon (R3) }\end{array}$ \\
\hline $0.3 \%$ (P1) & P1R1 & P1R2 & P1R3 \\
$0.5 \%$ (P2) & P2R1 & P2R2 & P2R3 \\
$0.7 \%$ (P3) & P3R1 & P3R2 & P3R3 \\
$0.9 \%$ (P4) & P4R1 & P4R2 & P4R3 \\
\hline
\end{tabular}

Crude fiber content was analyzed by filtering the fat-free sample, adding $1.25 \%$ sulphuric acid and heating for $30 \mathrm{~min}$. The residue was filtered and added with $1.25 \%$

$\mathrm{NaOH}$ solution before $30 \mathrm{~min}$ heating. The residue was washed, dried and weighed before ashing. The residue weight difference before and after ashing is defined as crude fiber content.

\section{Results and Discussion}

\section{Dried matter content of lowland tidal grass}

Dry matter content consisted of both organic and inorganic matter, the former was further degraded into simpler components like crude fiber, crude protein and NFE (Tillman et al., 1998). The average dry matter content as products of lowland tidal grass fermentation by probiotic microorganisms is presented on Table 2.

The results of variance analysis showed probiotic microorganism did not significantly affect $(P>0.05)$ dry matter content of lowland tidal grass. Oryza rufipogon grass's lowest dry matter content $(96.83 \%)$ was in $0.7 \%\left(\mathrm{EM}_{4}\right)$ and the highest $(99.63 \%)$ was in $0.3 \%$. Accordingly, the higher EM4 percentage the lower dry matter content because nutritional substances dissolved during fermentation. Moreover, Sandi et al. (2012) stated that silage $\mathrm{pH}$ decreased as $\mathrm{EM}_{4}$ addition increased. Ratnakomala et al. (2006) reported lower silage dry matter content $(32.50 \%)$ in elephant grass than that with $\mathrm{EM}_{4}$ fermentation.

\section{Crude protein content}

The average crude protein content as products of lowland tidal grass fermentation by probiotic microorganisms was presented on Table 3. Analysis of variance showed that probiotic microorganisms or $\mathrm{EM}_{4}$ significantly $(P<0.05)$ affected crude protein content of lowland tidal grass. However, the interaction of $\mathrm{EM}_{4}$ addition and variety of grass showed no significant effects. The lowest crude protein content $(8.41 \%)$ was in $0.3 \% \mathrm{EM}_{4}$ and the highest (13.43\%) was in $0.7 \%$ EM4 on Hymenachne amplexicaulis grass. Likewise, Santoso dan Hariadi (2008) reported 13.6\% crude protein in tropical grass. Higher results were obtained by both Adrianton (2010) and Jelantik and Belli (2010) on elephant grass with $8.86 \%$ crude protein on various grass cutting intervals.

Table 2. Mean effect of probiotics on the level of use of the dry matter content of some types of marsh grass (\%)

\begin{tabular}{lcccc}
\hline \multirow{2}{*}{$\begin{array}{l}\text { Dosage of } \\
\text { Probiotics }\end{array}$} & $\begin{array}{c}\text { Type of Lowland Tidal Grass } \\
\text { Rugosum (R1) }\end{array}$ & $\begin{array}{c}\text { Hymenachne } \\
\text { amplexicaulis (R2) }\end{array}$ & $\begin{array}{c}\text { Oryza } \\
\text { rufipogon (R3) }\end{array}$ & Mean \\
\hline $0.3 \%$ (P1) & 97.63 & 98.01 & 99.63 & 98.42 \\
$0.5 \%$ (P2) & 97.37 & 97.29 & 98.08 & 97.58 \\
$0.7 \%$ (P3) & 97.38 & 97.61 & 96.83 & 97.27 \\
$0.9 \%$ (P4) & 97.47 & 97.84 & 98.26 & 97.86 \\
\hline Mean & 97.46 & 97.69 & 98.20 & \\
\hline
\end{tabular}


Table 3. Mean effect of probiotics on the level of use of the crude protein content of some types of marsh grass (\%)

\begin{tabular}{lcccc}
\hline $\begin{array}{l}\text { Dosage of } \\
\text { Probiotics }\end{array}$ & \multicolumn{3}{c}{ Type of Lowland Tidal Grass } \\
\cline { 2 - 4 } & $\begin{array}{c}\text { Ischaemum } \\
\text { Rugosum (R1) }\end{array}$ & $\begin{array}{c}\text { Hymenachne } \\
\text { amplexicaulis (R2) }\end{array}$ & $\begin{array}{c}\text { Oryza } \\
\text { Rufipogon (R3) }\end{array}$ & Mean \\
\hline $0.3 \%$ (P1) & 9.52 & 10.95 & 8.41 & $9.62^{\mathrm{a}}$ \\
$0.5 \%$ (P2) & 10.04 & 12.22 & 9.27 & $10.51^{\text {aa }}$ \\
$0.7 \%$ (P3) & 12.25 & 13.47 & 10.16 & $11.96^{\text {bb }}$ \\
$0.9 \%$ (P4) & 12.16 & 13.09 & 8.93 & $11.37^{\text {ab }}$ \\
\hline Mean & $10.99^{b}$ & $12.43^{b}$ & $9.19^{\mathrm{a}}$ & \\
\hline Values bearing different superscripts within row and column are significant differences (P<0.05)
\end{tabular}

Further analysis using Least Significant Difference test showed that $0.3 \%$ probiotic microorganism addition $(9.62 \%$ crude protein content) did not differ significantly from $0.5 \%$ (10.51\%), but differed significantly from both $0.7 \%(11.96 \%)$ and $0.9 \%(11.37 \%)$. On the other hand, $0.5 \%(10.51 \%)$ was significantly different from $0.7 \% \quad(11.96 \%)$ but no significant difference was noticed in $0.9 \%$ (11.37\%). At last, $0.7 \%(11.96 \%)$ was not significantly different from $0.9 \%$ (11.37\%).

Varities of grass showed significant differences. Crude protein content of Oriza rufipogon grass $(9.19 \%)$ differed significantly from both Ischaemum rugosum (10.99\%) and Hymenachne amplexicaulis (12.43\%) grass, which was not signfiicantly different. Cude protein content increased with the increasing probiotic addition. During fermentation, microbial cells in $\mathrm{EM}_{4}$ preparate were grown and multiplied by energy and nitrogen source from urea. The microrganisms were the source of single cell protein. Consequently, protein content increased. Setiawati et al. (2013) reported that probiotics on catfish could improve feed efficiency and protein retention, and support optimal nutrients utilization in feed. Preliminary study showed Hymenachne amplexicaulis grass without probiotic microorganisms contained $7.11 \%$ crude protein but increased to $13.47 \%$ after $0.7 \%$ probiotic microbes fermentation. There was $47.22 \%$ increase in crude protein content.
It revealed that probiotic microorganims could improve crude protein content. During fermentation, lactic acid was produced as primary metabolite which preserved silage. In other words, lactic acid prevented silage from spoilage by spoilage bacteria (Widyastuti, 2008; Supriyantono and Santoso, 2010).

\section{Crude fiber contents}

The average crude fiber content as product from lowland tidal grass fermentation is presented on Table 4. Analysis of variance $(P<0.05)$ showed significant effect of probiotic microbes on crude fiber of grass. However, the interaction between probiotic and grass varieties revealed no significant effects. The lowest crude fiber content $(28.45 \%)$ was found in $0.7 \%$ on Hymenachne amplexicaulis grass, and the highest (35.07\%) was $0,3 \%$ on Oryza rufipogon. It was lower than 39.28 and $46.13 \%$ by Damry (2009) on grass at Lore Utara Subdistrict, Poso District.

Least Significant Difference test result indicated that treatment with $0.3 \%$ probiotic microorganism addition (contained 33.36\% crude fiber content) did not differ significantly from that with $0.5 \%(32.48 \%)$, but differed significantly from both $0.7 \%(29.62 \%)$ and $0.9 \%$ (30.16\%). While $0.5 \%$ (32.48\%) was significantly different from that of $0.7 \%$ (29.62\%), no significant difference was noticed in $0.9 \%(30.16 \%)$. 
Table 4. Mean levels influence the use of probiotics to the crude fiber content of some types of marsh grass (\%)

\begin{tabular}{lcccc}
\hline & \multicolumn{3}{c}{ Type of Lowland Tidal Grass } & \multirow{2}{*}{ Mean } \\
\cline { 2 - 4 } Probage of & $\begin{array}{c}\text { Ischaemum } \\
\text { Rugosum (R1) }\end{array}$ & $\begin{array}{c}\text { Hymenachne } \\
\text { amplexicaulis (R2) }\end{array}$ & $\begin{array}{c}\text { Oryza } \\
\text { Rufipogon (R3) }\end{array}$ \\
\hline $0.3 \%$ (P1) & 35.01 & 30.61 & 35.07 & $33.36^{\text {aa }}$ \\
$0.5 \%$ (P2) & 33.46 & 29.82 & 34.16 & $32.48^{\text {aa }}$ \\
$0.7 \%$ (P3) & 29.12 & 28.45 & 31.29 & $29.62^{\text {bb }}$ \\
$0.9 \%$ (P4) & 29.29 & 29.40 & 31.79 & $3016^{\text {ab }}$ \\
\hline Mean & $29.27^{\text {a }}$ & $29.57^{\text {a }}$ & $33.07^{\mathrm{b}}$ & \\
\hline
\end{tabular}

Values bearing different superscript within rows and columns are significant differences $(\mathrm{P}<0.05)$

Varities of grass showed significant differences in crude fiber content. Crude protein content of Oriza rufipogon grass (33.07\%) differed significantly from both Ischaemum rugosum (29.27\%) and Hymenachne amplexicaulis (29.57\%). Crude protein in Ischaemum rugosum (10.99\%) did not differ significantly from Hymenachne amplexicaulis (12.43\%), Oriza rufipogon (29.27\%), and Hymenachne amplexicaulis (29.57\%).

Crude fiber content decreased with the increase in probiotic use (up to $0.7 \%$ ). There was greater microbial activity in grass fermentation which resulted in simultaneous higher crude fiber content and decrease in crude fiber content. During grass fermentation, microbes produced enzymes which degraded fibers. Lignocellulose breakdown would release nitrogen, thus decreasing crude fiber content.

Other study showed that Hymenachne amplexicaulis grass without probiotic microorganisms contained $33.67 \%$ crude fiber, but decreased by 15.50 to $28.45 \%$ after $0.7 \%$ probiotic microbes fermentation. Probiotic microorganims was proven to lower the crude fiber content. Bacteria in EM4 degraded cellulose and hemicellulose into simple sugars. As supported by Widyastuti (2008) that during fermentation, cellulose and hemicellulose were hydrolized by bacteria into sugars. A part of the bacteria fermented the simple sugars into lactic, acetic and butyric acids.

\section{Conclusion}

The use of probiotics could improve the nutritional value of lowland tidal grass. The best result was obtained on kumpai tembaga grass (Ischaemum rugosum) fermented with $0.7 \%$ probiotic microorganism.

\section{Acknowledgement}

The author expressed thankfullness to Directorate General for Research and Public Service of Indonesian Ministry for Education and Culture for financing the research through Hibah Bersaing scheme in 2011.

\section{References}

Adrianton. 2010. The growth and nutritive value of elephant grass on different defoliation intervals. J. Agroland 17(3):192-197. (In Indonesia).

Allaily N, Ramli and R Ridwan. 2011. The quality of local-feed-source-based complete feed). Agripet 11(2):35-40. (In Indonesia).

Ali AIM, S Sandi, Muhakka and Riswandi. 2012. The quality of forage in Lebak pasture swamp of Pampangan buffaloes. Proceeding of InSINAS 2012. 307-312.

Damry. 2009. Production and nutritive content of wild pasture forage in Lore Utara Sub-district, Poso District. J. Agroland 16(4):296-300. (In Indonesia).

Farizaldi. 2011. Forage productivity on palm oil plantation of different age groups in PTPN 6 Batanghari District, Jambi Province. J. Ilmiah 
Ilmu-IImu Peternakan 14(2):68-73. (In Indonesia).

Jelantik IGN and HIL Belli 2010. Effect of urea or coconut cake supplementation on nutrient intake and digestion of bali cows mantainend on tropical grass hay. JITV. 15(3):196-204.

Khulug AD. 2012. Potential of Sugar cane Waste Utilization as Probiotic-Fermented Feed. Industri. 4(1):37-45. (In Indonesia).

Lembah Hijau Multifarm. 1999. Training Module of Integrated Farming System. CV. Lembah Hijau Multifarm-Research Station, Solo. (In Indonesia).

Linggarjati KF, A Djunaedi and Subagiyo. 2013. Test Use of Bacillus sp. as Probiotic Candidate for Crab (Portunus sp.) Farming. J. Marine Res. 2(1):1-6. (In Indonesia).

Muhakka, Riswamdi and AIM Ali. 2014. Supplementation of bioplus probiotic on Bali cattle growth with main feed of fermented kumpai tembaga grass (Hymenachne acutigluma). National Seminar of Western BKS Public Universities. Faculty of Agriculture, University of Lampung, Bandar Lampung, 19-21 Agustus 2014. (In Indonesia).

Ratnakomala S, R Ridwan, G Kartina and $Y$ Widyastuti. 2006. Effect of Lactobacillus plantarum $1 A-2$ dan $1 B L-2$ inoculant on the quality of elephant grass silage. BIODIVERSITAS 7(2):131-134. (In Indonesia).

Sandi S, AIM Ali and N Arianto. 2012. The nutritive quality of sugar cane shoots (Saccaharum officinarum) with Effective Microorganisme-4 (EM4) inoculant addition. J. Peternakan Sriwijaya 1(1):1-9. (In Indonesia).

Santoso B and BTj Hariadi. 2008. Chemical composition, nutrient degradation and in vitro methane production of tropical grass preserved in silage and hay methods. Media Peternakan 31(3):128-137. (In Indonesia).

Setiawati JE, Tarsim, YT Adiputra and S Hudaidah. 2013. The effect of adding probiotics to the diet with different doses on the growth, survival, feed efficiency and protein retention of catfish (Pangasius hypophthalmus). e-Jurnal Rekayasa dan Teknologi Budidaya Perairan. 1(2):151-162. (In Indonesia).

Steel RGD and JH Torrie. 1993. Prinsip dan Prosedur Statistika (Principles and Procedures of Statistics). Gramedia Pustaka Utama, Jakarta. (In Indonesia).

Supriyantono and B Santoso. 2010. Introductions of feed silage to livestock in Karya Bersatu Small-Middle Enterprise and Darussalam Aimasi Islamic Boarding School. J. Ilmu Peternakan 5(2):81-85. (In Indonesia).

Tanuwiria UH, A Yulianti and N Mayasari. 2006. The potential of feed-crops-originated waste and its capacity to the ruminant livestock population in Sumedang region. J. Ilmu Ternak 6(2):112-120. (In Indonesia).

Tillman AD, H Hartadi, R Soedomo, P Soeharta and S Lebdosorkojo. 1998. IImu Makanan Ternak Dasar. Gadjah Mada University Press, Yogyakarta. (In Indonesia).

Widyastuti Y. 2008. Silage fermentation and the benefits of silage probiotics to ruminants. Media Peternakan 31(3):225-232. (In Indonesia).

Wina E. 2005. The technologies of microorganisms utilization in feed to improve the productivity of ruminants in Indonesia: A Review. Wartazoa 15(4):173-186. (In Indonesia). 